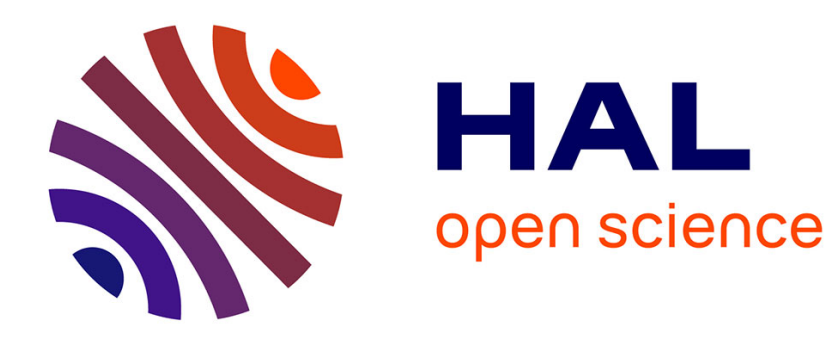

\title{
Adolescent masculinities and juvenile justice in France
} Arthur Vuattoux

\section{To cite this version:}

Arthur Vuattoux. Adolescent masculinities and juvenile justice in France. Norma, 2017, 13 (2), pp.103

- 118. 10.1080/18902138.2017.1421814 . halshs-01849060

\section{HAL Id: halshs-01849060 \\ https://shs.hal.science/halshs-01849060}

Submitted on 17 May 2019

HAL is a multi-disciplinary open access archive for the deposit and dissemination of scientific research documents, whether they are published or not. The documents may come from teaching and research institutions in France or abroad, or from public or private research centers.
L'archive ouverte pluridisciplinaire HAL, est destinée au dépôt et à la diffusion de documents scientifiques de niveau recherche, publiés ou non, émanant des établissements d'enseignement et de recherche français ou étrangers, des laboratoires publics ou privés. 
[Version non-éditée de la référence suivante : Vuattoux, A., "Adolescent masculinities and juvenile justice in France", NORMA, vol. 13, n², 2018, p. 103-118]

\section{Adolescent Masculinities and Juvenile Justice in France}

Arthur Vuattoux, Université Paris 13, Institut de recherche interdisciplinaire sur les enjeux sociaux (IRIS), F-93017 Bobigny Cedex, vuattoux@univ-paris13.fr

The material and analyses presented in this article are based on research conducted on the juvenile justice system in France and more specifically on how boys are treated within this institution. My main aim is to take a primarily qualitative approach to understanding how practices within the French justice system construct norms of masculinity, and to exploring the relationship between the institution's construct of deviant identities and the apparent performance of these identities by the youths. The idea of gender bias in the legal chain was first discussed in North American feminist criminology research and is currently being further developed in the field of feminist surveillance studies (Dubrofsky \& Magnet, 2015). This research has introduced gendered inquiry into work on sentencing and deviance (Dowd, 2008; Vanhamme \& Beyens, 2007). These studies have contributed to expanding the concept of deviance, which had until then been limited to looking at men (or women in extreme cases, e.g. murders), and, when gender was considered, had inversely been confined to analysing women's behaviour. (Cardi, 2007, Smith \& Paternoster, 1987).'

Some context is necessary in order to understand the main issues at stake in the research presented here. In France, a juvenile judge's competence extends to both "civil" cases (providing "educational assistance") and "criminal" cases. When a case is opened because the public prosecutor's office has been apprised of a situation placing a minor in danger, this falls under the remit of civil justice and the judge deals with protecting the minor in question (whether from him or herself, his or her family, or a third party). When the case is opened after a minor has been arrested for committing a

\footnotetext{
${ }^{1}$ Here, gender is meant as the outcome of social relations based on a differentiated understanding of individuals according to their sex. Beyond this sex-related bias, the concept also points to the institutionalisation of differentiated expectations for girls and boys, based on socially dominating gender representations.
} 
minor offence (délit) or a serious crime (crime), this falls under the remit of criminal justice. In such cases, the minors are judged for their actions according to a specific penal procedure and specific sanctions that differ from those applied to adults (prison sentences for a serious crime, for example, are halved). The overwhelming majority of criminal cases in juvenile justice concern boys (9 defendants out of 10, approximately) whereas civil justice is more gender equal (just over 1 boy for every girl). In criminal cases and in educational assistance alike, the legal framework for juvenile justice in France is largely marked by its post-WW2 legacy, which encourages viewing minors as specific subjects of the court who are difficult to judge as adults and require highly individualized procedures. Educational measures are given priority over penal outcomes, in theory at least, and in cases pertaining to educational assistance, children are only placed in care as a last resort when they can no longer remain in their families. Finally, juvenile judges work in both criminal and civil courts (which is not the case for adult cases) and are responsible for both investigation and sentence. In the legal texts framing juvenile justice, this specific feature is explained by the supposedly high degree of permeability between the living conditions of teenagers brought before the justice system (and therefore the need to protect them) and the fact that they embark on a deviant trajectory (and therefore the need to punish them). This perspective on juvenile life paths is strongly embedded in the operational structures of the legal institution, in terms of both practices and professional discourse on the matter (Chantraine \& Sallée, 2013).

Studies have already shown the gender bias at work in the French justice system. It is a wellestablished fact, for example, that female adolescents benefit more widely from the individualized procedures in place. Even when they are delinquents, measures of protection are often used to deal with their cases (for example, through social or healthcare support). Conversely, boys tend to be less "protected" by the justice system and more likely to face sanctions when they commit reprehensible acts (Cardi, 2007; Vuattoux, 2014). Nevertheless, until now, no study in France has ever really examined the situation of boys faced with the justice system through the prism of gender and, more specifically, in terms of norms of masculinity. This question underpinned part of the fieldwork on which this article is based, which was conducted in two French juvenile courts (Créteil and Paris) between 2011 and 2013. I based this research on the analysis of recent criminal and civil 
cases for both male and female deviance. Regarding male youths, my investigation consisted in quantitative analysis and qualitative analysis of 161 case files, 117 of which were criminal and 44 of which were civil. Having had only limited access to the court's archives, the case files were chosen by series, e.g. files from the months of February to April, opened by such judge. Altogether the research covered part of the casework from three different judges. It is to be noted that all judicial records analyzed in this paper are presented as concerning cis boys by the justice system. Further, all names of youths and professionals mentioned have been anonymized.

The present article will focus on the qualitative aspect of the research, which consisted in discourse analysis, drawing from the various parts of a judicial record: hearing reports, police reports, educational reports, reports from private or public security services, by local authorities, healthcare reports, letters from parents to the judge, etc. Beyond a 'formal' assessment of the judicial situations of the minors, I aimed to identify social categories used by educators and magistrates (whose notes are kept in the judicial files), but also to build an understanding of the youths' trajectories through cross-checking information from the numerous reports regarding their socialization and their lives prior to appearing in court. In parallel, I also conducted an ethnographic study, using interviews and observation, with different actors within the court. To this effect, I only used case files that had already been closed, so that said actors could react to my primary analysis during the research.

The aim of the research was to understand the discursive logic operating in the judicial institution: how is a deviant behaviour interpreted depending on the sex of the individuals? How do the accounts of the different actors manifest and reproduce norms of masculinity? How are different types of violence or behaviour described? To investigate these questions, the comprehensive analysis was based on the different components of the case files, particularly the educational reports produced by the various institutions responsible for young people to assist judges in their decisions, as well as the actual decisions made, and the context in which they were reached: in particular, I observed several dozen hearings at the Juvenile court in order to better understand the interactional 
workings underpinning these written legal documents. An additional layer of analysis was made possible by the fact that the case files had already been read by judges and assigned a decision. The observation of what was underlined and annotated allowed to form an understanding of the judges' reading process regarding the events and of the interview transcripts.

Subsequently, one should note that different 'discourse regimes' coexist within the overall written material. While all discourses analyzed are made about the youths, they range from being close to oral discourse (for instance hearing transcripts), to taking a different angle, as in the case of a letter written by a boy's parents to the judge or of an education report. It is important to keep in mind that each part of the case files has different specificities.

Beyond the discursive aspect, and while the youths have not been directly interviewed, we can read ways of "doing gender" (West, Zimmerman, 1987) which have been well documented so far, through this proposed analysis. Further, as this article is based on a study of professional practices, it aims to question, as suggested by Baumgartner, the " practitioners' ideas around masculinity in YJS [Youth juvenile system], on the Practice Level, and the incorporation of assessments forms of young males to explore how, if at all, masculinity does or can play a role in youth justice policy, on the Policy Level » (Baumgartner, 2012, p.83). From daily practice to penal policies, from individual agents' practices to their institutionalisation, the focus will be on the institutional practice of gender. Investigating the social construction of gender from institutional practices (Douglas, 1986) required to understand the gendered mechanisms at play within the institution, with the backdrop of a system heavily influenced by its founding ambivalence between protection and punishment, between education and repression. This system is also marked by an "emblematic figure" of deviance: boys from a lower-class background, highly represented in the population dealt with by juvenile justice. By producing knowledge on youth labelled as deviant, and by forming their judicial, social, educational paths, social control institutions construct deviant identities that will be performed by the youth which this article looks at. 
Looking at masculinities, one of the guiding hypotheses of my work was that agents in the justice system tend to equate boys' deviant behavior with a diffuse form of "hegemonic masculinity" strongly associated with risk-taking and violence. From this point of view, analyzing these case files allowed me to test on the ground some of the theories elaborated by works of reference on hegemonic masculinity (Connell, 1995; Connell \& Messerschmidt, 2005) and, more specifically, on adolescent boys facing the justice system (Dowd, 2008; Messerschmidt, 1999). While reference to "hegemonic masculinity" has been very present within the recent import of research on masculinities to French academia, it should certainly be used with caution. We must remember that "hegemonic masculinity" is an absolute norm, not necessarily performed by individuals in particular (Connell \& Messerschmidt, 2005, p. 838). Further, the original equation between hegemonic masculinity and violence has been nuanced by recent research looking to re-think new forms of domination in so-called 'egalitarian' societies, in which men's power is no longer necessarily achieved through violence, but finds many other means of reproduction (Hearn et al., 2012)

First, I will put to test the homogenizing principle equating adolescent deviance to violence, before looking at the differentiation between hegemonic and marginalized masculinities (Connell, 1995) revealed by the reading of the case files in my study, which helps better qualify the situation of the boys in the justice system. Finally, I will show the diversity of masculinities and manifestations of 'deviance' observed on the boys and how it affects institutional production on its margins.

\section{Male adolescent deviance and violence}

The definition of masculinity in academia seems to be intrinsically linked to violence. As Connell (2000) has remarked, this link is obvious if we look to the main figures of violence in society: men make up the overwhelming majority of state agencies of force (i.e. the people who exercise socially 
legitimate forms of violence, in the police, the military, etc.) as well as the overwhelming majority of those controlled by these agencies (after, in some cases, having used socially non-legitimate forms of violence). Confrontation between violent individuals and institutional repression of this violence is therefore a masculine confrontation. In this sense, "men predominate across the spectrum of violence" (Connell, 2000, p. 214).

Undoubtedly, the notion of "hegemonic masculinity" is one used by academia to understand situations such as those presented below, yet it also seems to be present in the representations formed by different actors (judges, educators), though probably not with this exact term, but through the way they associate the behaviour of boys in the justice system to their assumed gender, linking masculinity and violence. Indeed, this association is in keeping with a general structure of power relationships in society characterised by heteronormativity (Wittig, 1992), that is to say the allocation of predefined roles to men and women, as well as "compulsory heterosexuality" (Rich, 1980) and its related norms of conduct in varied social contexts. Within this, the confrontation between people who exercise socially legitimate forms of violence and other men can be perceived as a collective construction of masculinity, requiring all men (youths as much as policemen) to perform specific practices, including resort to violence.

Many studies have been conducted from this perspective regarding male adolescent deviance. The present research has confirmed the need to examine the commonly accepted link between male adolescent deviance and violence. For example, Nancy Dowd (2008) has tried to understand the link between the harsh punishments dealt out to men in the justice system and how hegemonic masculinity is perpetuated. According to her, juvenile justice reinforces representations linking masculinity, danger, and violence (Dowd, 2008, p. 132). By failing to question the fact that it deals with an almost exclusively male population, the justice system naturalizes transgression and frames the propensity for violence as necessarily masculine. Dowd's argument is the following: by handing out harsh punishments to violent men and boys, the legal institution reinforces the hegemony of all men, because it confirms the idea that men have a "natural" tendency for violence (Ibid., p. 132- 
133).

In the same line as Dowd's work, many studies focusing on masculinities before the justice system have used the concept of "hegemonic masculinity" developed by Raewyn Connell, which she defines as: "the configuration of gender practice which embodies the currently accepted answer to the problem of the legitimacy of patriarchy, which guarantees (or is taken to guarantee) the dominant position of men and the subordination of women" (Connell, 1995, p. 77).2

It is no doubt that boys in conflict with the law in part display this kind of masculinity, as Dowd seems to suggest: the high number of cases of violence against women (particularly sexual violence) involving adolescent boys would seem to confirm this. However, it is also true that there is a limit as to how far these teenage boys can be equated to this hegemonic position. As Adam Reich has noted, young male delinquents are symbols both of hegemonic masculinity and of marginalization in society (Reich, 2010, p. 16). Based on an empirical study, Reich also highlights the diverse forms of masculinity he observed in a juvenile prison. Based on his interviews with the prisoners, he underscored that not all the juvenile delinquents relayed sexism and violence against women (Ibid.). When the deviance of young boys is analyzed in detail, it does not fit with any homogenizing principle framing the latter as simple archetypes of hegemonic masculinity (Messerschmidt, 1999).

\section{Adolescent deviance and marginalized masculinity.}

In this section, I will bring in the concepts of marginalized masculinity and borrowed gender scripts to qualify the apparent interpretation by the justice system of the behaviour of boys it deals with. To do so, I will discuss three cases chosen from the legal files I studied at the juvenile court. These three cases relate to the legal trajectories of boys aged 14 to 17 at the time of the judgments. These young men's deviant profiles were strongly marked by violence, which they generally perpetrated but sometimes also experienced. Their actions were largely directed against institutions representing institutional power and the State. Their rebellion led them to use violence, but also insults and

\footnotetext{
${ }^{2}$ It should be noted that while hegemonic masculinity does not necessarily include physical violence in its definition, violence is generally considered acceptable when coming from males; violence renders hegemonic masculinity deviant, yet this deviance is tolerated by society.
} 
humiliation. Once arrested, they rarely expressed any remorse and maintained a position of strength towards their victims. This appeared to lead the judicial institution to construct the boys' identities as "'hegemonic masculinity", which undermined addressing actual needs of young men, with an approach skewed in favour of punishment over rehabilitation.

Nevertheless, in the face of power and the State, these boys were marginalized: they were failing at school in a society that emphasizes cultural capital; they were arrested by the law enforcement agencies they were trying to escape; and they tended to have suffered violence in families they had rejected or that had rejected them. More generally, their situations related to a form of social and cultural illegitimacy, particularly in terms of gender, class and age relations. Arguably, they could be considered as borrowing certain features of hegemonic masculinity while at the same time remaining on the margins of this socially legitimate form of masculinity.

As Connell notes, "hegemony is likely to be established only if there is some correspondence between cultural ideal and institutional power, collective if not individual" (Connell, 1995, p. 77). However, young men like these possess neither cultural nor institutional legitimacy. They are therefore much further from hegemonic masculinity than they are from a form of "marginalized masculinity" (Ibid., p. 79), defined as a form of masculinity that is dominated by the legitimacy of hegemonic masculinity: "Marginalization is always relative to the authorization of the hegemonic masculinity of the dominant group" (Ibid.). Thus, even though the violence that certain adolescents express towards institutional authority or towards subordinate individuals does relate to hegemony, the latter is always more firmly located among the groups responsible for controlling this violence. Sociological analysis of these boys' legal situations underscores the limitations inherent to any reading of their institutional trajectories that is purely framed in terms of "hegemonic masculinity". Let us first take two cases that are fairly commonplace and that offer an everyday illustration of a form of masculinity that tends to be considered violent and "hegemonic".

Brandon (all names have been changed in this article) was being prosecuted for "insulting" and "forcefully resisting" a security guard of the national rail service (SNCF). In an interview with the police, a security guard described the actions of the 16-year-old boy and his group of friends: "We 
got off at X station [a station in a suburb near Paris] in order to collect our service vehicle. In the tunnel of the station, a group of around ten individuals started insulting us, calling us "faggots" and "bastards". We moved towards them to ask them to leave the premises. When they went through the turnstiles, the individuals continued to insult us, calling us "bastards, pieces of shit, faggots" and then they said to us: "Come outside, we'll shoot you down". We only inspected one individual as the others had moved further away. The individual we inspected was one of the ones who had insulted and threatened us, so we detained him. He fought us off, pushing me away by my shoulder. Given the situation, we handcuffed him. Projectiles were thrown in our direction, so we took cover inside the station to protect ourselves. We called the police and handed the individual over to them" (police report, interview with security guard).

This description of a young man's violence, provided by the victim, features several elements: on the one hand, physical violence (Brandon fighting back when he was detained - although this could be interpreted as violence responding to violence - but above all, projectiles being thrown at the security guards by his group of friends) and, on the other hand, verbal violence, with the reported insults and threats. This violent situation entailed a confrontation between a group of young men and a group of male representatives of legitimate violence (i.e. law enforcement), a very common event in cases of teenage boys brought before the justice system. The violence in question here therefore set violent juvenile masculinities against institutional masculinities: it was a violent interaction between two groups of men. The details of the police reports also reveal a shared sense of resentment between both parties. By calling the police, the SNCF security guards (who were already in charge of law enforcement) indicated their desire to "make a point" in the face of this violence and have Brandon prosecuted. Brandon himself showed no remorse when interviewed by police: "Male police officer: What happened and why did you act like that? Brandon: I dunno, I was with my buddies, I wanted to play the tough guy, and look what happened - I'm the only one down here". Male police officer: Do you regret what you did? Brandon: No." (police report, interview with Brandon).

In this case of violence between men, judged by a man (the case was presented before a male judge), everything seems to boil down to relations of violence. The case file contained almost no 
information about the young man's personality, apart from an educational report that was very concise - probably because the case did not seem particularly serious to the youth workers tasked with producing it for the proceedings. Despite the charges filed by the public prosecutor's office, the judge decided to "dismiss" the case with no penalty. This decision was not surprising in the context of French criminal law, where is it uncommon for acts like these to be prosecuted and where they would usually remain at the level of a score being settled between the young men and the security guards, without involving a judge or even the police.

Another case fairly similar to Brandon's illustrates the commonplace nature of situations of violence between groups of youths and law enforcement agencies. Amin was 17 and being prosecuted for "insults", "forceful resistance" and "violence". His "history" (i.e. the previous cases filed against him, which were recorded by the court and allowed the judge to link this case with previous ones) showed that he had been in court many times, for 13 different offences, which had led to 9 decisions and 9 cases (4 of which were still on-going). Amin was the only individual arrested for attempting to damage public property but, on the day of the offence, he was actually part of a group of youths who decided to try and pull up some bollards in place to prevent twowheeled vehicles from entering a park. As in Brandon's case, the moment when he was handcuffed crystallized a situation of both verbal and physical violence. The police report gave the following version of events: "I informed the young man I was going to handcuff him. At that precise point in time, he spoke to me as follows: 'Go fuck yourself, you motherfucker'. I stretched his right arm out in order to put the first handcuff on. He fought me off violently, kicking officer Barel". Shortly after Amin was handcuffed, the situation degenerated and the violence seemed to escalate. The police officers described it as follows: "[Shortly after], several individuals from the cité [projects] hurled themselves at me to free their friend. My colleagues formed a shield to try and control the surge. Despite that, certain individuals managed to reach me and tried to grab my arms to allow the detainee to run away. Almost immediately, I noticed an administrative weapon on the ground a few meters away from me. Officer Segond put his foot on it, picked it up and put it in my holster (...). I found myself lying on the ground grappling with the detainee, received several blows to try and make me let go of the detainee. That must have been when my firearm was taken from its holster 
(...). I requested back up using the emergency beacon and several vehicles arrived as back up, allowing us to contain the situation" (police report, description of the arrest by the police officers). The police officer writing this report described a situation escalating out of control, which, despite being eventually contained, could have had serious consequences given that a weapon was lost during the altercation. The description seems to waver between reminders of police power (they ultimately managed to handle the situation, despite everything) and the flaws of the arrest. One part of the interview with Amin seems to have attracted the judge's attention, as he underlined it several times in the case file. The text reads as follows: "Male police officer: Did you fight back during the arrest? Amin: When the police officers searched me, I didn't struggle, but when the police officer grabbed me by the throat, I fought back, I pushed him so that he'd take his hands off. Your colleague in uniform and I dropped to the ground, I was punched in the face and the police officers handcuffed me. Given the situation, I was angry, I was really wound up. Your colleagues picked me up and took me to the police car" (Police report, interview with Amin, whole section underlined by the judge and highlighted with arrows).

The judge in question was no longer in office when I conducted my investigation, so I was not able to interview him. Based solely on the case file, I can therefore only hypothesize why he underlined this section along with all the others that recounted the actions of the police officers when the young man was arrested and restrained. However, it does seem plausible that he considered the actions of the police officers to be disproportionate given the offence committed, perhaps even a form of police violence. One way or another, he handed down a paradoxical sentence, partly acquitting the young man (on the charges of violence) and yet granting the civil damages requested by the police officers (who were each awarded $250 €$ ).

These examples are representative of the strong presence of physical violence in cases where adolescent boys are judged in court. The case files I studied provided some context for this violence and it was clear that it tended to occur in a relational manner, when they were faced with representatives of public power. Isolated acts of violence, outside a context of generalized violence, were rare. We can therefore reasonably suggest that violent aspects fit into the more general way society is structured around violence, whether it is socially accepted (on the part of law enforcement 
agencies) or not (on the part of young delinquents).

This does beg the question, however, of whether boys' violence can really be reduced to this simple notion of masculine confrontation (between groups of youths, or between youths and law enforcement). Certain situations of violence require a more detailed reading, one that takes particular account of the extent to which this violence is enrolled in asymmetrical power relations. When male violence is guided by asymmetrical power relations and caught up in the structural framework of men dominating women or, in the present case, non-hegemonic figures of masculinity, it corresponds to a form of hegemonic masculinity par excellence.

The case of Tarek, arrested at age 14 for "theft from a vulnerable adult" and "insulting" a police officer, presents an irrefutable example of violence and domination inflicted on another person. From this perspective, the first salient feature of the theft was that the victim was disabled. The case file stipulates that the person came from the same neighborhood and was well known among its inhabitants. When Tarek was interviewed by police officers, he left no doubt about how he viewed the victim: "He's lying, I never hit him, he's not normal”. And yet Tarek had already been arrested in the past for mistreating this man (slapping him, in that case). Acting violently towards a vulnerable adult clearly corresponds to the definition of "hegemonic masculinity", in which gender domination is effected by exercising power over individuals who do not correspond to hegemonic criteria (i.e. being a man, being strong, being able-bodied, etc.). Attacking a disabled person can be seen as just another means through which hegemonic masculinity is performed and norms are reinforced.

Various elements in Tarek's file confirm the young boy's demonstrations of hegemonic masculinity. In an interview with youth workers cited in the legal file, Tarek's mother described him as "unmanageable" and explained that she was worried about the company he was keeping: Tarek apparently often "hung out" with an older man, who lived in the same building and was an alcoholic. Tarek's mother also mentioned numerous nights spent away from home, most likely involving alcohol and "dubious" company, according to her. The case file also included a summary drawn up by the district public security services to inform the public prosecutor's office about a worrying situation. An excerpt from that report shows that the institutions responsible for social 
control were concerned by the increase in delinquent acts committed by Tarek and that this concern was exacerbated by his young age: "The serious nature of the acts minor Tarek is accused of shows a substantial increase in this 14-year-old minor's delinquency. At just under 15 years of age, he has already faced 19 legal proceedings. Five took place in the first trimester of 2008, when he was only thirteen years old. The penal outcomes seemed to indicate that Tarek had realized the gravity of his acts, as he was not involved in any further legal proceedings until February 2009. However, Tarek then went back to his delinquent ways and was implicated in eleven proceedings between February 2009 and October 2009. He has carried on in that vein in 2010 with three proceedings already ongoing, on top of the three I have described. It is clear that this minor wants to assert himself on the ground and is engaging in alarming behavior towards institutions such as the police or the justice system" (Report drawn up by the district public security services).

This report not only revealed an individual in conflict with the establishment, with no apparent fear of legal proceedings given the overwhelming number he had faced, it also illustrated a certain institutional awareness of the symbolic motivations behind violence among certain youths. For the authors of this report, Tarek demonstrated a desire for power ("he wants to assert himself") that was clearly directed against public institutions. The professionals in question saw Tarek's attitude as the sign of a long-lasting involvement in delinquency. As we have seen, the young man's violence was also clearly directed against vulnerable people who did not correspond to his ideal of masculinity. This aspect was not mentioned much by the professionals, but was implicit in the sentence the young man received, which was particularly harsh and explicitly cited the victim's vulnerability as an aggravating factor. Indeed, while his two accomplices, both older than him, were sentenced to pay civil damages or given suspended sentences (with community service), Tarek was sentenced to 15 days in prison, which is a fairly rare sentence for a minor in France, as discussed in the introduction.

Both Amin and Tarek demonstrated forms of violence that were taken at face value and dealt with as such by the institution. The penal outcomes and their justifications framed the young men as violent deviants.

However, it appears worth questioning the motives behind this use of violence, beyond an 
understanding of their actions as manifestations "hegemonic masculinity". Their violence can be seen, as often in the case of young boys in the justice system, as a reputational concern, or « interpersonal sovereignty »(Jackson-Jacobs, 2013, p.30). There seems to be a challenging of their masculinity, within an interaction understood at a micro-sociological scale (Randall Collins, 2008) characterised by the (male) sex of those involved. More generally, it was observed in their case files that their apparent desire for domination often came up against much more efficient forms of domination that preceded their own actions: the societal domination responsible for repression or imprisonment and, more generally, the everyday domination that keeps teenagers like them in a subordinate position in most aspects of their lives. Those societal reasons emerge to explain the teenage boys' resistance of their marginalization through the use of gender scripts borrowed from hegemony (violence, rejection of disabled persons, etc.).

Indeed, violence is all-pervading in cases concerning boys, both quantitatively and in terms of the representations at work (and therefore, in terms of institutional expectations). Consequently, this makes it hard for practitioners to read situations in which male teenagers' gender display actually reveal vulnerabilities and weaknesses, or simply features that mean their actions cannot be reduced to violent demonstrations of hegemonic masculinity. This, in turn, affects decisions made about them.

\section{Multiple masculinities and homogeneous institutional representations}

What role does the justice system play in reproducing the most common norms of masculinity, which strongly associate deviance, violence, and risk-taking?

Everything seems to point to the fact that conventional gender expectations about boys tend to mask any alternative gender displays that are less in line with the institution's expectations. However, a small number of the case files I examined clearly revealed forms of vulnerability that were incompatible with the prevailing concept of "hegemonic masculinity". From their marginal 
position, these cases offer a way of understanding the logics of homogenizing representations that play out in juvenile justice.

Four case files, in particular, provide examples for analyzing these logics. Some of them clearly show that the judicial process failed to take into account weaknesses or other non-hegemonic aspects of masculinity, while others bring to light situations when the institution was forced to take them into consideration. Finally, some files also reveal situations in which the young men in question countered gender expectations more or less directly.

Julien was a teenager of just under 18 years of age, who had been in "educational assistance" (protection of minors) since he was 15, after the Conseil Départemental (District Council) was alerted to his case because of family problems. Julien showed signs of a behavioral disorder identified by various professionals, particularly at school, which he eventually stopped attending. He spent most of his time at home, shut away in his room. An educational report from an open (i.e. non-residential) institution clearly referred to his problems: "Julien says he has headaches and stomach aches when he has to leave home" (educational report written about Julien). Furthermore, according to Julien's mother, he only washed once a week and refused any external constraints. The educational report concluded that this situation revealed a "pathogenic family relationship" and implicitly accused the parents of educational failings (especially the father, who was systematically absent from the hearings). Julien was eventually placed in a children's home and prescribed antipsychotic drugs, which he soon stopped taking. In Julien's case, the judicial institution was clearly faced with a specific disorder that required some form of medical treatment, which did begin when he was first taken on board. However, after several failed attempts at treatment, the institution began instead to make decisions aimed at finding Julien employment. First, the judge followed the conclusions of a report advising that measures be taken to officially diagnose his mental handicap, specifically in order "for Julien to be able to find a job" (under French law, certain jobs are reserved for people with a recognized handicap). Then, while Julien was being looked after in a nonresidential institution, it was suggested that he be sent to a psychiatric hospital in the south of France that "focused on future employment". Nonetheless, despite these recommendations, once Julien was 18, the judge closed his "educational assistance" case and the boy was admitted in 
psychiatric care. All the plans that had been suggested for him, combining healthcare and a professional future, were dropped, partly due to the administrative complexity of this kind of case and partly due to the lack of financial resources available to the civil justice system. In cases such as Julien's, the legal institution appears powerless in the face of adolescents' actual needs.

Sometimes, however, medical and psychological treatment does appear essential to the institution, both in educational assistance and in criminal cases. Sven, for example, was prosecuted for threatening his brother with a kitchen knife. He lived in a difficult family environment, in a large impoverished family (he had seven brothers and sisters, four of whom lived under the same roof). The educational report about Sven indicated the youth worker's surprise when she interviewed him in jail. Sven had broken down in front of her and said he "needed help" to solve his problem with violence. She therefore advised that he should receive treatment: "The question of treatment has to be raised, because it seems clear that Sven needs a space where he can talk" (educational report concerning Sven). Sven was particularly shocked by the police intervention. When he was arrested, after his mother called for help, Sven was holding the knife and the police officers therefore drew their weapons. This event had deeply affected him. During the court proceedings, a psychiatric expert report indicated that he required psychiatric treatment.

After an investigation and a period of educational observation, the judge decided to simply issue a "warning". In this situation, the judge could have decided to drop all charges from the outset but chose instead to keep the proceedings open (this was clearly why he ordered the investigation and educational observation) in order to find out more about Sven's problems. This indicates an awareness of the difficulties the boy was facing, particularly the psychological problems that seemed to be tormenting him. While, ultimately, this approach did not lead to any long-term healthcare treatment, Sven's file does show that the institution paid attention to his psychological issues, above and beyond the question of the act he committed. In this situation, the institution seems therefore to have disrupted its usual routine procedures (mainly aimed at handling cases quickly and efficiently) in order to deal with the specific situation of a vulnerable boy. Finally, another configuration revealed by the case files I studied concerns young men whose profiles seem to directly counter conventional gender expectations. This was the case for both Basile and Brian. 
Basile was an only child of 17 years who had both an "educational assistance" and a criminal case open. The civil case was opened because his parents directly requested it: his case file indicates that his parents asked for him to be placed under educational assistance following a meeting with youth workers in the context of a criminal case. The parents' strong involvement in the procedure is evidenced by the many letters they sent to the judge over that period. In these letters, written in a distinguished and meticulous style, the parents said they were worried about Basile's misdemeanors, especially his involvement in criminal affairs. They wrote, for example, that: "We know (...) that adolescence is a very difficult time for a young man and it is both necessary and constructive for him to be in opposition with his parents but, in the present case, Basile is destroying and compromising his future adult life (dropping out of school, refusing any help through his passivity, refusing to be an actor in his own life): our reactions to this are getting worse and worse, as we are concerned. Nothing seems important to him anymore except being with his group of friends" (Letter from Basile's parents to the judge).

The strong involvement of Basile's parents - from a middle-class background, with no other children - was also mentioned by the educational services trying to explain Basile's actions. The youth workers noted that his parents' concern and educational commitment seemed to have had the unwanted effect of further weakening the parent-child bond. After a two-week educational investigation, Basile was placed in a children's home in the region. The youth workers in this institution described Basile's demeanor and appearance as unusual for a boy placed in a home (or at least, not often described by these services): "Basile is a young man who takes care of himself and his belongings. His room is always tidy and he is always well dressed and well groomed. Concerning his appearance, Basile is keenly aware of the image he presents. He enjoys the physical appearance workshops, where he can take care of himself. He recently changed his hairstyle, which was previously fairly eccentric, in order to be more presentable for an internship interview (...). He constantly keeps his distance from the various conflicts that sometimes arise in the home. The girls in the group often seek him out, but he also has a certain reserve, which heightens the impression that he is inaccessible. Basile is discreet about his past and in expressing his feelings, and his attitude towards the other youths inspires a form of empathy and respect on their part" (Educational 
report from a children's home about Basile). Basile seemed to stand out through a dissonant display of gender (at least, that is what the discourse relating to him lead to think: he took care of himself, he kept his distance from others, especially girls) but one that was not stigmatized within the institution: the report indicates that the other youths there respected him. In his case file, the gender scripts of male deviance seem to come up against a stumbling block in the shape of his complex personality. His actions prove difficult to interpret in terms of rejection of institutions, violence towards women and other men, or putting virility to the test. In this sense, Basile's case defies all the usual modes of characterization applied to deviance among boys.

Non-conventional masculinity can also be portrayed in cases involving a complex relationship to sexuality and gender. This was no doubt the case in the case file concerning Brian, a 17-year-old boy facing criminal prosecution for rape and sexual assault. The offences he was being prosecuted for took place in his early teenage years, when he was between 9 and 13 years old.

Brian was turned in by friends of his parents, based on allegations of sexual assault made by their two daughters. The charges against him were potentially very serious in terms of criminal law: Brian was accused of cunnilingus, fellatio, and ejaculating on the girls' bodies (both of whom were his age at the time of the events). Furthermore, during the proceedings, a second charge emerged from his brother, Jordan, who also accused him of fellatio and anal penetration. The judge summarized the facts (admitted by Brian) as follows: "Brian admitted in his very first interview having caressed Melissa and Annabelle's genitals, with their consent, according to him. He also mentioned attempts at vaginal penetration with his fingers. He added that, on several occasions, he had rubbed his naked genitals on the young girls' genitals until he ejaculated. He specified that these acts had begun when he was 11 years old (...) he also said he had committed sexual acts on his younger brother Jordan, referring to mutual fellatio and two full anal penetrations with ejaculation, after having wet his penis with saliva. He explained that this behavior had been prompted by watching a pornographic film while on holiday at his father's home" (judicial order). This reference to a pornographic film watched at his father's home introduced the question of his parents' sexuality, often absent from case files of this kind but very present in this particular case because of its "unusual" nature. Both Brian's parents, now separated, mentioned their past or 
current homosexuality in the proceedings. During a police interview, his father explained that he had had homosexual relationships before meeting Brian's mother, while the latter had moved in with a woman since their break up. Although the parents mentioned these aspects of their private lives in a purely informative manner, the simple fact they were mentioned in Brian's case file seemed to reveal a specific institutional interest in the matter, on the part of the judge but above all the medical experts tasked with shedding light on Brian's situation. The first psychiatric export about Brian at the beginning of the proceedings gave the following summary: "Brian presents with a serious sexual disorder, which was the reason for the offences he is charged with. He seems to have a certain fascination with marginal sexuality due to his very particular family situation and especially his mother's homosexuality. Everything he says is hypersexualized and he seems to be overcome with the issue of defining his sexual identity, to the exclusion of all other concerns. His identity-related difficulties, his capacity for acting out and his lack of stimulus barrier mean that this situation is likely to repeat itself, with Brian either the perpetrator or the subject of the offences" (Psychiatric expert report).

In this case file, the parents' sexuality - considered "deviant" in terms of commonly accepted social norms which tend to assume, in most cases, that the parents of children in the justice system are heterosexual - was an overwhelming factor in how the situation was analyzed. In the psychiatrist's report for instance, it is homosexuality that seems to be the problem and that is alleged as having consequences on Brian. As he seems to be facing identity-related difficulties, this is linked in the report to a lack of stable markers regarding sexuality (this analysis assumes that not having strictly heterosexual parents is in and of itself a reason for identity crisis).

This position on Brian's sexual identity was later called into question by other events which offered a more commonplace explanation for his acts: a previous sexual assault suffered by the minor who is himself charged with sexual assault. The father of the two girls assaulted by Brian admitted having raped Brian several years earlier. Following this revelation, a second psychiatric report was drawn up which contradicted the first one, stating that it was the trauma Brian had suffered when he was raped that led him to become a sexual offender himself. It is worth noting that within the analysis of families' internal rape cases, the link between being a victim of sexual abuse and 
becoming a perpetrator is frequent. However, the data available does not allow to indicate a causal link between both; it merely indicates that sexual assaults committed within the family structure are relatively common, once the judicial institution gets a closer look at internal family relationships. Nonetheless, the young boy continued to be explicitly categorized as a "pervert" in several components of the case file (expert witness reports and educational reports). Brian was therefore defined by a deviant relationship to sexuality, which seemed to echo other forms of sexual "deviance", whether legal (his parents' homosexuality, implicitly labeled as deviant by the institution) or illegal (the sexual assault he suffered at the hands of a male friend of the family). Homosexuality being considered by the institution as a deviance from the implicit heteronormative model, the distinction between a victim of sexual abuse in their childhood and the child of parents whose sexuality is not conform to the expectations of the institution seems blurred. Following further offences on his part, Brian continued to face criminal sentences throughout his teenage years.

The way in which the institution dealt with Brian's situation seems to confirm the hypothesis that the judicial institution reproduces diffuse forms of heteronormativity (Dowd, 2008), by associating certain sexualities to deviance, and by considering that these sexualities necessarily question the future of children they are in charge of. For instance, the initial interpretation of the judge assumes that not having strictly heterosexual parents is in and of itself a reason for identity crisis). This situation also reveals the extent to which unusual gender performance, in the context of family justice where the heterosexuality of parents is always presumed, can trigger confusion within the actors (Bulter, 1995).

These non-hegemonic masculinities, or masculinities that actively counter institutional expectations about men and boys, allow the academic debate about masculinities to move forward. It is clear here that the young men prosecuted by the justice system - who are often reduced to representations in which masculinity is inherently violent - in fact display a wide range of masculinities. These non-hegemonic figures of masculinity, sometimes visible on the margins of the case files analyzed, are often invisibilized during criminal proceedings because of preconceptions about male 
adolescent deviance. Progress within the academic debate has not thus far translated into a space being carved among the 'occupational discourse' in France around the concept of gender as a key one to work around.

\section{Conclusion}

In evaluating the situations of adolescent boys, working on their difficulties and delinquent acts, and deciding what consequences should ensue, the justice system channels gendered representations of deviance. These representations are coded in legal language, but often appear implicitly in the attention that is paid to certain features in the adolescent boys' personal, family, or social circumstances. They appear to be portrayed by agents in a way that fits an understanding of their behaviour in line with hegemonic masculinity. However, a deeper analysis shows how signs of vulnerability are overlooked thereby failing to see their marginalization and borrowing of gender scripts, and mostly ignored in the decision-making process. In this particular context, sociological research has shown that this is especially the case for young men from lower-class neighborhoods (Mohammed, 2011) and within institutions that represent State legitimacy, such as school (Depoilly, 2014).

Following Mary Douglas's hypothesis (1986) according to which institutions produce legitimate representations of the social world and incite their members to "think" in terms of those representations, we could even suggest that, to a large extent, the deviant trajectories of these adolescents are a product of the institution that deals with them. Indeed, the boys' deviance is read by the judicial institution along the norms of masculinity that it "expects", linking deviance and forms of violence and risk-taking (particularly the risk of ending up in court). It should be noted that it is the institutions that produce representations, and not each separate agent. There are clear differences in practices among professionals, local specificities, and even protests against the institution when it reinforces or produces gender norms. Still, the sociological analysis of the case files allows to understand the weight of the institution in leading to a social and gendered treatment 
of the boys, characterized by the reproduction of the most common gender norms, marked by heteronormativity and the equation between boys and a hegemonic masculinity.

Based on a qualitative reading of legal case files, this article has shown that the deviant trajectories of adolescent boys cannot actually be read through a homogeneous lens, whether in terms of their display of masculinity or in terms of how institutions respond. In reality, certain situations reveal specific forms of vulnerability that do not correspond to the gender expectations usually relayed by the institution. In these cases, the boys' vulnerability sometimes emerges through an educational report or a medical expert report, and changes the way deviant adolescent masculinities are approached by the justice system.

I would therefore suggest that, even though the institution produces relatively fixed representations of deviant adolescent masculinities, the way these masculinities seem to be performed by the adolescents in question can change institutional practices and discourse on its margins. By emphasizing the actual masculinities displayed by these teenage boys, this article was able to reveal the wide range of masculinities at work. The adolescents, whose bodies are both objects and agents in social practice (Connell \& Messerschmidt, 2005, p. 851), show just how impossible it is to reduce their situations and actions to any fixed, homogeneous figure of masculinity.

\section{Références}

Baumgartner, E. (2012). And then there were the men: masculinity and the Youth Justice System in England and Wales. Graduate Journal of Social Science, 9, 79-86.

Butler, J. (1990). Gender Trouble. New-York: Routledge.

Cardi, C. (2007). Le contrôle social réservé aux femmes: entre prison, justice et travail social. Déviance et société, 31, 3-23.

Chantraine, G. \& Sallée, N. (2013). Éduquer et punir. Travail éducatif et discipline en établissement pénitentiaire pour mineurs. Revue française de sociologie, 54, 437-64.

Collins, R. (2008). Violence. A Micro-Sociological Theory. Princeton: Princeton University Press.

Connell, R. (1995). Masculinities. Cambridge: Polity Press.

Connell, R. (2000). The Men and the Boys. St Leonards: Allen \& Unwin.

Connell, R., \& Messerschmidt, J. (2005). Hegemonic Masculinity: Rethinking the Concept. Gender \&Society, 19, 829-859. 
Depoilly, S. (2014). Filles et garçons au Lycée pro. Rennes: Presses Universitaires de Rennes.

Douglas, M. (1986). How Institutions Think. Syracuse: Syracuse University Press.

Dowd, N. (2008). Boys, Masculinity and Juvenile Justice. Journal of Korean Law, 8, 114-134.

Dubrofsky, R. \& Amielle Magnet, S. (Ed.). (2015). Feminist Surveillance Studies. Durham, London: Duke University Press.

Ferguson, A. A. (2000). Bad Boys. Public Schools and the Making of Black Masculinity. Ann Arbor: University of Michigan Press.

Hearn, J., Nordberg, M., Anderssonn, K., Balkmar, D., Gottzén, L., Klinth, R., Pringle, K., Sandberg, L. (2012). Hegemonic Masculinity and Beyond: 40 Years of Research in Sweden. Men and Masculinities, 15, 31-55.

Jackson-Jacobs, C. (2013). Constructing Physical Fights: An Interactionist Analysis of Violence among Affluent, Suburban Youth. Qualitative Sociology, 36, 23-52.

Messerschmidt, J. (1999). Making bodies matter: Adolescent masculinities, the body and varieties of violence. Theoretical Criminology 3:197-220.

Mohammed, M. (2011). La formation des bandes. Entre la famille, l'école et la rue. Paris: Presses Universitaires de France.

Reich, A. (2010). Hidden Truth. Young Men Navigating Lives In and Out of Juvenile Prison. Berkeley: University of California Press.

Rich, A. (1980). Compulsory Heterosexuality and Lesbian Existence. Signs, 5, 4, 631-660.

Smith, D. \& Paternoster, R. (1987). The Gender Gap in Theories of Deviance: Issues and Evidence. Journal of Research in Crime and Delinquency, 24, 140-172.

Vanhamme, F. \& Beyens, K. (2007). La recherche en sentencing: un survol contextualisé. Déviance et société, 31, 199-228.

Vuattoux, A. (2014). Adolescents, adolescentes face à la justice pénale. Genèses, 97, 47-66.

West, C., Zimmerman, D. H. (1987). Doing Gender. Gender and Society, 2, 125-151.

Wittig, M. (1992). The Straight Mind. Boston: Beacon Press. 